\title{
Colour Preference for Project Team Members in the Context of Their Team Role
}

\author{
${ }^{1}$ Kateřina Bočková, ${ }^{2}$ Dáša Porubčanová, ${ }^{3}$ Monika Dohnanská \\ ${ }^{1,2,3}$ DTI University, Dubnica and Váhom, Slovakia
}

\begin{abstract}
The presented paper discusses the colour and the possibilities of its perception as a reflection of the behavioural preference in the project team. Colour is examined as a mean of expressing the personality preference and the associated characteristics. The aim is to compare the preference of a team role defined by Belbin (2003), (2004) with colour preference in the context of team work in the project team, to try to find the answer to the question of whether the preference of a specific colour reflects the preference of a team role. The paper contains an analysis of the data obtained from a detailed questionnaire survey $(\mathrm{N}=69)$ carried out in two successive steps, followed by a synthesis of the findings to verify the hypothesis $\mathrm{H}$ : The preference level of a team role differs from the preference of a particular colour.
\end{abstract}

Keywords: Team role, Belbin, Project team, Colour

\section{Introduction}

With the gradual development of technology, the volume of information in visual form is increasing. Unlike a written form, the picture can capture and convey higher amount of data, objects, relationships between them, or even the emotional charge of the captured situation. And along with the increasing amount of pictorial material that surrounds us, the importance of knowing each of its elements and their meaning is currently growing. Colour, as one of the first stimuli, that we analyse and evaluate when looking at a thing, man or situation, have gained an unreplaceable space in the symbolic conception of the world around us with the development of human culture. They are attributed to different meanings and characteristics, both based on our own experience and, on the other hand, on their meanings in general, stemming from the cultural environment in which we live and, therefore to the entire group, the community. Symbolic meanings are associated with colour to the extent that they can serve as a means of sharing information about ourselves, own feelings, characteristics, preference, etc. In the context of colour psychology, especially the question of the psychophysiological effects of individual colours on an individual was examined, as stated by Clark (1984); Brožková (1982); Lüsher (1991), (1997) or Pleskotová (1987). On the other hand, it is generally known that our colour preference can tell us a lot about our character, as claimed by Veverková (2002) or Mlynářová and Orlita (2006).

The team role, as described by Belbin (2003), (2004), combines the needs of the group respectively of the working team to meet the chosen goal and the individual as the bearer of dispositions. In teamwork, essentially as in any other social group, several possible roles are determined. Belbin (2003), (2004) determined nine key roles for teamwork and prepared a personality inventory to identify them, which determines the magnitude of the tendency to behave in one of the defined ways. Here, it is worth highlighting the fact that despite some negative characteristics, the individual roles are a selection of "beneficial" patterns of behaviour. The intentional and conscious selection of a colour is also behavioural in a particular social situation (Picco and Dzindolet, 1994; Kitao and Kitao, 1986). It is, therefore, possible to assume that there is a relationship between the team role and the preference of colour.

\section{Literature Review}

\subsection{Teamwork}

The team is determined as a formal social group with knowledge and skills related to a specific field and the stated goal, 
which primarily mentions Belbin (2012), Kolajová (2006), Hayes (2003), Kubátová et al. (2013), Meier (2009) and Krüger (2004), and so the processes taking place in the social group are taking place in each project team. Many authors today point out that the team approach to product creation and service delivery is not only more and more frequent but also an increasingly important strategy in terms of effective implementation of corporate goals (Bělohlávek 2008, Hayes 2003, Meier 2009, Hájek 2012, Hlušička 2012). Bělohlávek (2008) even talks about teamwork as a competitive advantage; both because it is effective and, on the other hand, it is rare, which puts it on top over the finance, business strategy, or technology.

As part of a joint solution, cooperation should take place in an atmosphere of interaction, understanding, and creativity (Barták 2007, Plamínek 2009).

Knowing the personality of the individual, his uniqueness, and his individuality is, in this case, strategically important from managing the work process, optimizing the use of workers, and preventing conflicts or eventual individual failures. The analysis of the complex of assumptions, abilities, knowledge and, last but not least, of the features and characteristics enables us to make responsible decisions about the correct selection of employees, and at the same time, it provides the information to the bearers of these qualities about its qualities and possible options.

\subsection{Team Role}

Team roles are the equivalent of a social role in a specific social group, the team. Individual team roles are influenced by the composition of the group, the individual characteristics, and the characteristics of the individuals who make up the group (Výrost and Slaměník 2008, Kolajová 2006, Plamínek 2008). In this respect, the personality disposition and, on the other hand, the norms and expectations of the group, the team, are important.

In the field of personnel and human resource management, R. Meredith Belbin dealt with more detailed research into the issue of the different personality and effectiveness of management teams. Based on nine years of research, in which participants were subjected to a battery of psychometric tests and observation work teams, R.M. Belbin and his colleagues at Henley Management Collage identified several typical behavioural groups while working in a team later named "team roles." The team role describes some preferred behavioural patterns that individuals use to interact with others as they contribute to the problem-solving process within the group (Belbin 2003, 2012). It is not just a personality characteristic in general, but an important one is a set of factors that contribute to the formation of a pattern of behaviour directly in the context of teamwork. According to Bělohlávek (2008, p. 29), who works with the M.R.Belbin model in his publications, the construct of the team role is "partly a manifestation of personality, innate characteristics and, in part, such a demonstration of experience gained".

One of the most important elements of Belbin's grasp of the notion of team role is the fact that it is primarily about the individual's preference, whether determined by personality factors or experience. Each of the roles is a sum of other abilities, skills, and behavioural traits, and hence the potential strengths and weaknesses that may emerge in working together. These preference for behaviour is not unchanging and are not the same for each situation. The individual characteristics and roles are theoretically unambiguously differentiated, but Belbin himself (2003) admits that in practical life, it is a complicated process; individuals rarely come up with a stable pattern of behaviour in situations requiring teamwork. Most populations have 3-4 preferred roles that they can take, or change based on the situation they are in. Therefore, the team role does not represent a distinct personality type, the individual characteristics may occur together (Kolajová 2006, Bělohlávek 2008, Plamínek 2009).

\subsection{Colour}

"Colour is our earliest visual impetus and flows its way into the lowermost layers of the symbolic language of mind" (Kenner, 2007, p. 11). It is an attribute that we register as one of the first, often even before we ever find out what we are looking at (Veverková, 2002). It is generally known that colour is not the property of the object we see but the attribute of light that reflects from the object and falls on the retina of a wavelength. However, perceiving a wavelength spectrum as a spectrum of differentiated colours is not based on any physical delimitation that would uniquely determine the boundaries for that colour - perception of a particular colour and its distinction from others and the naming is the ability of the human mind, the human brain (Atkinson et al. 2003). Schirillo (2001) thinks this ability is one of the most exciting results of our mental activity.

In practice, there are often clear instructions on the meanings of colours and their interpretation based on experience or 
different stereotypes (Brožková 1982; Sasaki, according to Bilgin and Isler 2008). In the field of teamwork, it is especially literature dealing with correct performance, self-presentation, and effective nonverbal communication techniques, such as Tegze (2003), Tee (2005), and Lewis (1998) and others. These, however, present colour, particularly in connection with clothing and suitable colour combinations.

\subsubsection{Colour Preference and Personality}

The use of colour as a mean of value transmitting, that testifies about us to people around us, allows to present our own "I" to others, speaks about the extent of our self-evaluation (who I am and how I try to be perceived), Schneiderová (2008) says. We assume that the neighbourhood perceives and understands these forms of presentation approximately on the same level. There is a close context between colour and personality in this respect. There has been evidence of this context since antiquity. The most well-known model in this respect is originally the Hippocrates model of four temperaments, to which four representative colours were assigned (Hulke 2005; Lüscher 1997).

The combination of colour and personality or characteristics is not a matter of the past. As observer, we can derive and we really derive, either rightly or wrongly, the characteristics of others based on such information and suggestions as appearance, visual description, clothing, furnishings of bedrooms and offices, preference of musical style or colour (Gosling, et al., 2002; Gosling and Vaziri 2004 according to Lange and Rentrow 2007, Rentrow, 2003, Lange and Rentrow 2007, Monnet 1997).

One of the first to point out the possible context between colour preference and personality differences was Eysenck (1941 cit. Crozier 1999) or Lange and Rentrow (2007), who linked extroverts with clear and pure colours, while the preference of introverts was on the dull colours side.

The most famous supporter of the idea that personality features and preference of colours are together clearly linked, is M. Lüscher (1997), who based his research on assumes that individuals with similar colour preference also have similar personality characteristics. The psychological response to individual primary colours (blue, red, yellow, and green) is intended to reflect the psychological needs of the individual, says Lange and Rentrow (2007). The question of whether and to what extent colour preference is universal in view of the cultural context and personal experience is still the subject of research, for example, Crozier (1999) or Taft (1997 in Crozier 1999). Lüscher (1997, p. 118) speaks in this respect about the unambiguous similarities of the feelings that different people create in individual colours, regardless of the context. On the other hand, he recognizes the subjective distinct feelings of sympathy, indifference or antipathy that a person has against a colour. We can say that he defines the objective (independent on culture or context) and subjective (dependent on personal experience) quality of the perception's component, of feelings that colour evokes in us. His colour psychology is based on the absence of differences in the objective component of perception of individual colours. Crozier (1999), on the other hand, reflects the findings of several researches concerning the preference of colours and in the connection with personality characteristics as not unambiguous. The only repeating result is the approximate order of six basic colours (blue, green, red, yellow, black, white).

Except the context on unconscious mental content and processes, as is the case with Lüscher (1997), the researches into the relationship between personality and colour are focusing on the preference of colours as a conscious reflection of motives, values. Despite this, however, the authors often achieve different results - not always the context between colour preference and a personality characteristic is proven, says Lange and Rentrow (2007). The authors report that the difference in the results of similar research is due to the fragmentation of the problem (piecemeal problem). According to them, colour preference is not "linear," but one personality features can testify to more than one path, the "many-toone" colour preference. Verifying hypotheses based on this strategy they concluded that the preference of colour is significantly correlated with Strong's (1931) Basic Interest Scale and, to a lesser extent, with Cattel's (1957) 16 Personality Factors. In any case, it is possible to claim that there is a context between the preferred colour and personality characteristics. Based on colour preference, we can, to some extent, consider the personality of the other person

\section{Methodology}

The aim of the presented paper is to compare the preference of team roles defined by Belbin (2003), (2004) with colour preference in the context of project teamwork, to try to find the answer to the question whether the preference of a specific colour reflects the preference of a team role. 
The team role based on Belbin's concept described not only by Belbin (2003), but also by Bělohlávek (2008), characterizes the individuals with features and tendencies to behave in a way - to prefer a pattern of behaviour during the teamwork. This results from the interaction of the individual's personality, its acquired experience and, of course, also from the demands of the group, in the middle of which the team role is defined. The preference of team role proves the characteristics, features and preference of behaviour in the teamwork. Colour, especially if we use it as part of nonverbal communication, can become a representative of the characteristics we attribute to ourselves. Several researches prove that the preference of colour is associated with the perception of one's own personality features and individual characteristics of personality (Crozier 1999; Lange and Rentrow 2007; Lüscher 1997). At the same time, colour may be used as a non-verbal means of self-presentation and of attempt to obtain a positive assessment from the others, as claimed by Madden et al. (2000, pp. 90-107). It is obvious that colour preference is associated with some personality features and therefore can be used as a means of self-presentation, related to behaviour in a situation. The basis for our research is, therefore, this assumption: Values of the preference of a team role, and the tendency to behave in a way, are associated with the preference of the specified colours.

The hypothesis of the research is formulated as follows: H1: The scale of preference of a team role is different about the preference of colour. Furthermore, the zero hypothesis $\mathrm{HO}$ is formulated as follows: There are no differences in the preference of a team role due to the preference of colour. By rejecting the zero hypothesis $\mathrm{H} 0$ about the absence of a relationship between prioritizing team behaviour and colour prioritization, it would be possible to support the hypothesis of the existence of a reflection of preferred behaviour in colour choice.

The team role preference was determined based on the Belbin's Team Roles Self-Perception Inventory modified by Bělohlávek, which identifies the scale of tendency to behave in a way in the working environment. A questionnaire published in Bělohlávek (2008) was used. The colour meaning and the characteristics of preferred roles were deduced from the description of team roles (Belbin 2003, 2004, Bělohlávek 2008), with the same number of characteristics being selected for each role. Based on the choice of characteristics for the preferred colour, it is possible to see, what the preferred colour meaning for respondents is, and we could compare the colour's characteristics with the characteristics of respondent's preferred role. The research file was selected based on several criteria.

Due to the demonstrable dependence of colour preference on the cultural context, which is published in Wright et al. (2004), there was an effort to preserve the temporal and spatial coherence of the studied group to avoid the influence of cultural-historical, linguistic and geographical differences in the perception of individual colours. Therefore, the Czech and Slovak MBA students of the Business Institute, s.r.o. in Prague and Bratislava and of European School of Business and Management, s.r.o. Prague, study program Project Management and Planning, aged 38 to 46, studying in the abovementioned institutions in different cycles in September - October 2018, were included. Students of the study program are expected to have experience with the project teamwork. In the first place, the simple random selection method was used to generate a random number set (format corresponding to the student identification numbers of the listed institutions). A questionnaire in different variants was sent to the selected file. Since the questionnaire was administered by email and the possibility of participation in the research was voluntary, we can talk about some form of sampling of respondents; only those who were motivated enough answered. In total, 250 questionnaires were sent, the answer was sent back to 76 respondents, the return of the questionnaire was $30.4 \%$. In one case, the questionnaire was not correctly filled in, in one case the questionnaire format was not readable. Based on the reported colour vision disorder, one respondent was excluded from the research. The survey was attended by 69 respondents, including 36 women and 33 men. The difference between the genders is not significant and on the base of repeated researches the significant difference in male and female colour preference, except for the preference of a yellow colour that men prefer significantly less than women (Seefeld 1973, Lange and Rentrow, 2007), was not confirmed.

Considering the size of the research group, this research does not claim wide scope for generalizing the results, it may be at least a partial indicator in the population of today's generation of Czech and Slovak project managers and members of project teams. In our view, it is very difficult to investigate and generalize the results on the wider population, because the inhomogeneity of cultural and historical factors that may affect colour perception would distort the results.

\subsection{Methods Used}

The research was carried out in two consecutive phases. Considering the already mentioned colour dependence on the cultural context as well as the individual experiences, it was not appropriate to use any of the existing colour schemes 
because they were often created in a different environment and especially in another language. For example, commonly used Lüscher's primary colours are not considered to be representative of the given colour, their hue is specific (Lüscher's green is considered as blue green, etc.). That's why a new colour palette was created for our research. A pre-research was used to select typical representatives of individual colours. The 40 respondents, coming from the same population as the research respondent's population, it means, that we can suppose a similar perception of individual colours, were asked what colour they considered as "basic". Pre-research participants got acquainted with the purpose of the experiment, so they were excluded from further research to avoid potentially affecting the results (for example, the experimental expectation effect, as reported by Hendl (2004)). The result was a list of eleven "basic colours"; white, black, yellow, blue, red, orange, green, brown, grey, violet, pink. Subsequently, a large colour scale was presented to the respondents for the pre-research based on the RGB (Red - Green - Blue) colour model. This model was chosen because it uses additive colour mixing that better corresponds to our perceptual system and is common in computer technology (Žebrová, 2007). Respondents of the pre-research asked the question, which colour they consider to be a typical representative for each verbal naming of colours. The "typical" colour was chosen by more than 50\% of the respondents (which was achieved only in yellow and grey, in the case of white and black it was the absolute agreement of all respondents). If none of the selected colours met this limit, we narrowed the selection of colours to those that the respondents chose in the first round and we asked the question again. The pink and violet colour even after repeated attempts failed to reach any over-affinity, and therefore could not find a good representative. Therefore, these two colours were excluded from the next research phases. The colour values selected in the pre-survey are listed in the table (see Table 1).

A three-part questionnaire was created to determine the colour preference and to administer the team role test. The first part was a Belbin's Team Roles Self-Perception Inventory modified by Bělohlávek. For research, this version was deliberately chosen for several reasons. On the one hand, the Bělohlávek's test does not have an ipsative character such as Belbin's test, so it is possible to achieve several high (but low) results without adversely affecting the number of points in other types. This corresponds to Belbin's concept of several (3-4) optimal team roles and, on the other hand, allows respondents to describe their own behaviour without limitation. The disadvantage of this form is that an individual can stylize himself as a "superman" to achieve artificially high scores in multiple areas, or in all.

The test, questionnaire form of team role determination was chosen for several reasons; even when observed by professional and trained observers, there is a considerable disadvantage that not all individual preference can be reflected in the specific composition of the team. In this situation, one takes a role that is best for him and for the team (Belbin, 2003, 2004), and even a good observer is unable to identify other preference that might have been reflected in the other members of the team. In addition to lesser reliability, observation is demanding for staffing and time. The test, unlike observation, remains opened for various possible combinations of preference in teamwork. The individual properties are judged based on the perception of their own (corresponding) behaviour in the situations presented by the test.

Table 1: Typical colours

\begin{tabular}{|l|c|c|c|}
\hline Colour & Red & Green & Blue \\
\hline Black & 0 & 0 & 0 \\
\hline White & 255 & 255 & 255 \\
\hline Red & 255 & 26 & 0 \\
\hline Blue & 0 & 0 & 164 \\
\hline Green & 79 & 164 & 0 \\
\hline Yellow & 255 & 255 & 0 \\
\hline Orange & 255 & 133 & 0 \\
\hline Brown & 139 & 79 & 6 \\
\hline Grey & 106 & 106 & 103 \\
\hline
\end{tabular}

Source: Own

The second part consisted of a projective question about the preferred colour, the question directly focused on the teamwork environment was chosen to avoid the influence of other contexts and associations that could influence the preference of the colour. Thus, preference becomes a deliberate, not an unintentional act and thus a form of presentation of a statement bearing a meaning. The suitability of the projective question and its correct understanding was verified on 
a small set of 10 respondents, based on which the question was modified to the final form.

There are two ways of determining the colour preference, as stated by Hulke (2005): By direct stimulation with a colour impulse - the disadvantage of this method is the bias resulting from individual colour perception by a respondent. At the same time, since it is a direct stimulation, there are other disturbing effects of the context, surroundings (lighting, monitor parameters, colour resolution, etc.)

By imagining the colours associated with its naming - in this case, the disturbing effects of the environment are eliminated, but on the other hand, we lose control over what colour the individual represents under a name. Its different qualities (hue, brightness, and saturation) can lead to its different conception and other symbolism. That is why the first method - direct stimulation was chosen for this research. Respondents were directly exposed to colour stimuli for each colour in the same format. Because of the possible effect of the background as a context, the most common environment was chosen so that the respondents were not disturbed.

As the respondents filled out the questionnaire in an unchecked environment, the influence of other intervening factors that could influence colour perception, as well as the completion of a team role test, such as lack of light, disturbing factors affecting the respondent's attention and, last but not least, technical parameters and setting up of a computer, is not possible to exclude. To address these impacts, respondents were instructed within the e-mail about the approximate duration of the questionnaire and the need to provide appropriate lighting conditions in this respect. At the same time, they were asked to give enough attention to the issues. A possible intervention variable in connection with lack of motivation and of time or attention is also the inaccuracy in filling in the questionnaire. The solution in this case was the already mentioned offer of evaluation of the results, which motivated respondents to answer truthfully. Dishonesty could also appear because of trying to stylize into a position. In this case, we assumed that stylization would be present even in colour preference. This would compensate the intervening variable on both sides and the results are comparable.

The order of each colour of colour scheme pattern that was created in pre-research was varied in each variant to avoid the possible colour preference order. The third part of the questionnaire concerned personal data, respondent's gender, and the state of colour vision.

The generated questionnaire was administered to respondents by e-mail. Respondents were given the opportunity to evaluate the Belbin's Team Roles Self-Perception Inventory modified by Bělohlávek also to improve their motivation to complete the test and thus increase the return on the questionnaires. Different versions of the questionnaire were assigned to individual respondents. To counteract the possible effect of the order of Belbin's Team Roles Self-Perception Inventory modified by Bělohlávek and the choice of the preferred colour and its characteristics, half of the questionnaires were reversed; version A - BTRSI, Colour preference; Version B - Colour Preference, BTRSI. Together with a different order of colours, 725760 possible versions of the questionnaire ( $\mathrm{k}$ ! X 2) were created. Therefore, a different version was sent to each respondent on a random basis (the only condition was the same representation of both versions).

No complete explanation of the purpose of the questionnaire was sent to the respondents, only the team role test and its options were mentioned. Those, who sent back the completed questionnaire, we sent an email with a thank you and a complete explanation of the purpose of the questionnaire. After transcribing the data obtained into the data matrix and evaluating the team role test, respondents who showed interest were sent an evaluation of their test. We have respected the Personal Data Protection Act and did not use anything to encode the data on which the respondent could be identified. We also tried to respect the ethical rules of research and the work of a psychologist working out of EFPPA (European Federation of Professional Psychologists Association) requirements.

Ethically less correct is the way of selecting respondents. To randomize, we chose the "spam" method - an unsolicited email, in which some respondents could be considered harassment. This reduces the motivation of respondents to respond to a similar e-mail, or to answer truthfully, and to devote enough attention to the questionnaire.

Concealment of a specific experiment goal was treated by posting the complete intent to study.

After the test was delivery, each of the respondents was identified with a code that spoke of the version of the test he filled out. The parts of the test were evaluated and converted into a data matrix. The data obtained from the questionnaires were processed in Microsoft Excel. Sixty-nine questionnaires were included in the analysis of the results. Each of the 
questionnaires contained a different colour order, with 30 questionnaires of version A (43.5\%) and 39 questionnaires of version B $(56.5 \%)$.

\section{Result and Discussion}

A plant (PL) is the role significantly more than the average preferred by the respondents who chose the yellow colour. On the other hand, lower values than the rest of the group were achieved by the green group (the result does not exceed the level of statistical significance).

Co-ordinator (CO) and Resource Investigator (RI) are more than the other preferred team roles for respondents who have chosen the yellow colour. In the case of Resource Investigator, however, the value does not reach the level of statistical significance.

Shaper ( $\mathrm{SH}$ ) is the preferred team role for the group with the selected red colour. On the contrary, for green, the preference of this team role is lower.

Roles Monitor Evaluator (ME) and Complete Finisher (CF) did not achieve significantly higher or lower preference in any of the preferred colour groups.

Role Teamworker (TW) achieves a higher preference for a group of selected green and yellow colours. On the contrary, the red colour preference of the group is significantly lower. Roles Implementer (IM) and Specialists (SP) were more than preferred by a group of respondents who chose a blue colour.

Based on the results of the data analysis of 69 respondents, it can be argued that the hypothesis has been confirmed, respectively the zero hypothesis about the absence of differences in the preference of the team role relative to the preference of colour is refuted. The first result of the research described above was the determination of the colour scale, which offers a different set of typical representatives of individual colours: red, blue, green, yellow, grey, orange and brown. Given the size of the sample (40 respondents) and the narrow demarcation of the population, these results cannot be generalized very broadly. We have already encountered a problem of individual perception, categorization and naming of individual colours in pre-research. The exclusion of pink and violet colour from the impossibility of reaching any match in identifying typical representatives of these two colours indicates that colours are not predefined categories, and the method of categorizing of individual colours is dependent on subjective experience. It is possible that, if a larger research team were used in this respect, the pink and purple consensus could have been reached. However, the increase in the sample examined would reduce its homogeneity and the observed differences could even be greater.

Another finding that supports the idea that colour is a category that influences our perception and assessment of people, things, phenomena, could be the difference between returns of the A and B versions of the questionnaires (13\% difference). The version was rated first in a team role test, while the second version began with the prioritization of colours, coloured surfaces. One of the likely explanations for this difference is the ability of colour to attract attention and be the first visual signal we evaluate and on which basis we decide. It is possible, that respondents, who decide on the first impression of filling or unplanned test, were more motivated by the B colour scheme than the black-and-white A version after opening the attachment.

From the results of the team role test, it appears that in each selection of respondents the roles preference was approximately normal, and therefore the group surveyed approaches to the characteristics of the normal distribution existing in each population. Even though the respondents were able to get a total number of points, the average number of optimum roles, corresponding to more than 10 points, was only 2.34, less than Belbin declared (3-4). This means, on the one hand, that despite the possibilities, the respondents were critical of filling out the questionnaire. This fact also demonstrates the suitability of the respondents or the usefulness of the test results as a motivating factor.

Within the preference of individual colours, the most numerous groups were made by respondents who preferred the green colour. This conclusion confirmed the results of previous studies, which speak of the fact that the most preferred colour of the adult population is blue. Blue was second, but the difference between green and blue was not significant, and it is possible that with the larger sample examined, the ratio would turn in favour of the blue colour. 
On the other hand, the colours grey and brown and white were chosen little, or not at all. These are colours that do not generally belong to the first bars in the preference of individual colours (Crozier, 1999). Here, a corresponding explanation could also be the linking of the projective question to the preference of colours that evoked entry into the teamwork, with the meaning attributed to these three colours. Attempting to present yourself in the best possible light has probably led respondents to prefer colour to more pronounced. In examining the context of preference between individual team roles and colour preference, a significant difference was found in eight cases.

The research results confirm the existence of a context between colour selection and preference for a behaviour. It is possible to support the claim that colour or colour preference may reflect the preference of team roles and vice versa. Looking for a possible originator of this context, it is important to realize that as a preference for a team role, so the choice of the preferred colour that individuals have to represent in the working team environment, are essentially forms of behaviour in a specific social interaction situation. Personality as a dynamic source of individual behaviour, is involved in their relationship (Drapela, 1997). Both the preference of team roles and colours reflects some of the personality characteristics. Individuals with similar characteristics similarly prefer the team roles, and given the relative versatility (depending on the context) of the meanings of the individual colours, a particular colour may carry similar characteristics (in this respect the context between personality features and colour preference was supported by several types of research, e.g., Bilgin and Isler (2008) or Wolfarth (1985 by Viving 2006). The second important factor that could influence the found results arises from the projective issue of colour preference and of the context of entry into a particular social situation. The preference of colour could be influenced by the effort to present yourself in front of the others in the best possible way and thus to choose a colour that carries "good" and "positive" characteristics. The preference of the team roles detected based on the self-perceptive inventory, gives the respondent the opportunity to present himself to generate a good impression and a positive expectation (Výrost and Šlaměník 2008). Rozvadský Gugová (2014) states that the Self-concept expresses the unity of body and soul consistency and human continuity. It develops in an individual interaction with the world. Self-image can be defined as an attempt associated with the overall vision of yourself. It can be divided into three components: cognitive - how do I see myself, what I know about myself, emotional - how they are being evaluated, the degree of correlation between real and ideal me, how I am and what I want to be and ultimately regulative - how to handle one's own personality.

Significance is associated with a specific colour, which also reflects the conscious or desired characteristics. Also, an important factor is the possibility that colour does not serve as a representative of the currently perceived status of personality, but as an attempt to present yourself in the group in the best light. Given that, the specific significance, that is unknown to a given person, is unknown, it is difficult to interpret the context between preference behaviour - holding a team role and prioritizing colour at the level of individual meanings. Research results show only a combination of colour preference and a specific team role, they do not answer directly to the question why, although they provide some guidance. The yellow colour was preferred by respondents who, more than others, prefer the role of Plant (PL), Coordinator (CO), and Team Worker (TW). Just below the level of statistical significance, the Resource Investigator (RI) role remained. These roles, apart from the Plant, are included in the Belbin's concept among "people-oriented" roles. They have a common ground in focusing on working group relationships, the ability to communicate, motivate, and diplomatically respond to the situation. If we look for common characteristics with the Plant role, it is the flexibility and speed with which all these roles can handle the new situation. These roles are not characterized by knowledge or experience, but rather by the talent and the ability to adapt. In this respect, it can be found a parallel with the Lüscher characteristic of yellow as a colour associated with dynamics, change, and freedom, especially with the Plant's characteristics, as well as the Resource Investigator. Equally satisfying is the junction of yellow with creativity, lightness, resourcefulness, intelligence, and clarity.

High ranking in the role Teamworker is associated with a green colour preference. Green is rated stable, strong, persistent, and tough. These characteristics are no longer easy to relate to the role of the Teamworker. Possible connections are calm, creativity, and peace, which can be combined with diplomacy and the ability to adapt quickly and calm others. Given the low preference for the role of Plant and Shaper, the similarity of individual characteristics is more difficult to find than for other roles. An interesting combination is the result of the group preferring the red colour, which was associated with higher values in the role of Shaper (SH) and vice versa in the role of Teamworker. From the characteristics of the roles arises their contradictory position in relation to the others, to the degree of hardness, to orientation and values. In favor of the red link and the role Shaper also speaks psychophysiological effects of this colour - an increase in arousal, nervousness, as Arnheim (2004), Stone (2001, Lange and Rentrow 2007), or Kohoutek (2002) cited. Lüscher (1997) combines it with a sense of self-confidence and self-power, which further 
contributes to this connection. With the role of Teamworker, who is diplomatic, sensitive, assisting, we cannot find many common characteristics.

The last distinct connections are the higher preference for Implementer and Specialists in the context of blue colour preference. The common characteristic of both roles is the ability to work systematically and independently, critically thinking. From communal meanings, this combination would promote the meaning of blue emphasizing tranquillity, isolation, solitude. Maddon's (2005) interpretation of blue in the context of communicative people working on labour relations has not been confirmed. However, we must not forget that similar contexts are not the exact confirmation of the fact that the colours really have this meaning for the individuals who have selected them. The importance of colour cannot be separated from its affective and psychophysiological effect, so the preference of colour is the involvement of personality factors, culture, experience and physiological effect of individual colours.

\section{Conclusion}

The hypothesis that there is a relationship between the team role preference and the preference of a colour is confirmed. These results are probably related to the same origin of team role preference and colour preference in the personality characteristics and complex of everyone's experience. The perception of colour preference and of team role preference we consider as a selection clearly dependent on the context. The colour can be a good means of sharing and presenting of information to our surroundings on the base of the context in connection with subjective processing, experience and meanings, those are attributed to the colour in each cultural and historical environment. In this respect there is lot of researches (Eysenck 1941; Bakker, van der Voordt et al. 2015, Hanafi and Sanad 2015, Lange and Rentfrow 2007, Schaie 1966, Kaya and Epps 2004) dealing with the colour preference and personality characteristics. To what extent is the process of colour meaning attributing connected to personality, and to what depth the preferred colour and its meanings reflect the characteristics of a team role or personality itself, is a matter that would be worth exploring.

\section{References}

- Arnheim, R. (2004). Art and Visual Perception. Berkley: University of Kalifornia Press.

- Atkinson, R., L., Atkinson, R. C., Smith, E., E., Bem, D. J., and Nolen-Hoeksema, S. (2003). Psychologie. Praha: Portál.

- $\quad$ Bakker, I., Van Der Voordt, T., Vink, P., De Boon, J., and Bazley, C. (2015). Colour preference for different topics in connection to personal characteristics. Colour Research \& Application, 40(1). Crossref

- Barták, J. (2007). Vzdělávání ve firmě. Praha: Alfa Publishing.

- Belbin, R. M. (2012). Manažerské týmy. Praha: Wolters Kluwer Česká republika.

- Belbin, R.M. (2003). Team roles at work. Amsterdam: Elsevier.

- Belbin, R.M. (2004). Management teams why they succeed or fail. Amsterdam: Elsevier.

- Bělohlávek, F. (2008). Jak vést svůj tým. Praha: Grada.

- $\quad$ Bilgin, A., and Isler, A. S. (2008). Colour preference of children in terms of gender differences. E-Journal of New World Science Academy. 3(4).

- Brožková, I. (1982). Dobrodružství barvy. Praha: SPN.

- Cattell, R. B. (1957). Personality and motivation structure and measurement. New York: World Book.

- Clark, A. (1984). Physiological Response to Colour: A Critical Review. Colour Research and Application. 9 (1). $\underline{\text { Crossref }}$

- Crozier, R.W. (1999). The meanings of colour: preference among hues. Pigment \& Resin Technology. 28(1). Crossref

- Drapela, V. (1997). Přehled teorií osobnosti. Praha: Portál.

- Eysenck, H. J. (1941). A critical and experimental study of colour preference. The American Journal of Psychology. 54(3). Crossref

- Hájek, M. (2012). Životní fáze týmu. Retrieved from http://www.vedeme.cz/pro-vedeni/kapitoly-vedeni/66tymy/153-faze-tymu.html

- Hanafy, I. M. and Sanad, R. (2015). Colour preference according to educational background. Procedia - Social and Behavioural Sciences. $\underline{\text { Crossref }}$

- Hayes, N. (2003). Aplikovaná psychologie. Praha: Portál.

- Hendl, J. (2004). Přehled statistických metod zpracování dat: analýza a metaanalýza dat. Praha: Portál. 
- Hlušička, P. (2012). Tým a jeho potenciál. Retrived from http://www.firemní-sociolog.cz/cz/clanky/99-tym-ajehopotencial

- Hulke, W.M. (2005). Praktická kniha o barvách. Přáslavice: Fontána.

- Kaya, N., and Epps, H. H. (2004). Relationship between colour and emotion: A study of college students. College Student Journal, 38(3).

- $\quad$ Kenner, T.A. (2007). Symboly a jejich skrytý význam. Praha: Metafora.

- Kitao, K., and Kitao, S. K. (1986). A Study of Colour Association Differences Between Americans and Japanese. Human Communication Studies. 13(4).

- Kohoutek, J. (2002). Základy užité psychologie. Brno: CERM.

- Kolajová, L. (2006). Týmová spolupráce. Praha: Grada Publishing.

- Krüger, W. (2004). Vedení týmů: jak sestavit, organizovat a povzbuzovat pracovní tým. Praha: Grada Publishing.

- Kubátová, S. (2013). Tajemství spolupráce v týmech. Praha: Management Press.

- $\quad$ Lange, R., and Rentrow, J. (2007). Colour and personality: Strong's Interest Inventory and Cattell's 16PF. North American Journal of Psychology, 9(3).

- Lewis, D. (1998). Tajná řeč těla. Praha: Victoria Publishing.

- Lüscher, M. (1991). Test volby barev k hodnocení osobnosti. Bratislava: Psychodiagnostika.

- Lüscher, M. (1997). Čtyřbarevný člověk. Praha: Ivo Železný.

- Madden, T. J., Hewett, K., and Roth, M., S. (2000). Managing Images in Different Cultures: A Cross-National Study of Colour Meanings and Preference. Journal of International Marketing. 8(2). Crossref

- Maddon, T. (2005). Život podle barev. Praha: Ikar.

- Meier, R. (2009). Úspěšná práce s týmem. Praha: Grada Publishing.

- Mlynářová, A. and Orlita, V. (2006). Sebepoznání jako nutný předpoklad profesní úspěšnosti. Retrived from

- $\quad$ z http://www.orlita.cz/detail.php?clanek=75

- Monnet, B. (1997). Jak uspět v přijímacím pohovoru. Praha: Grada.

- Picco, R., and Dzindolet, M. (1994). Examining the Luscher Colour Test. Perceptual and Motor Skills. 79 (3). CrossRef

- Plamínek, J. (2009). Týmová spolupráce a hodnocení lidí. Praha: Grada Publishing.

- Pleskotová, P. (1987). Svět barev. Praha: Albatros.

- Rozvadský Gugová, G. (2014). SELF-concept and Marketing Strategies. Management Studies. New York, NY, USA. 2(4).

- Schaie, K. W. (1966). On the relation of colour and personality. Journal of Projective Techniques \& Personality Assessment, 30(6).

- Schirillo, J.A. (2000). Tutorial on the Importance of Colour in Language and Culture. Colour Research and Application. 26 (3). Crossref

- Schneiderová, A. (2008). Komunikační dovednosti: učební text pro distanční studium. Ostrava: Ostravská Univerzita v Ostravě.

- Strong, E. K. (1931). Change of interest with age. Stanford: Standford University Press.

- Tee, R. (2005). Jak úspěšně zvládnout přijímací pohovor. Brno: Computer Press.

- Tegze, O. (2003). Neverbální komunikace: co vám prozradí lidské chování a jednání a jak toho využít. Praha: Computer Press.

- Veverková, L. (2002). Psychologie barev: prožívání barev a jejich preference. Československá psychologie, 46(1).

- Viving, L. (2006). Why We Think Blue is Calming: Colour-Mood Associations as Learned or Innate. Retrieved from http://www.geocities.com/huntgoddis/appendixe.doc

- Výrost, J. and Slaměník, I. 2008. Sociální psychologie. Praha: Grada.

- Wright, P., Mosser-Wooley, D. and Wooley, B. (2004). Techniques \& Tools for Using Colour Computer Interface Design. Retrieved from http://www.acm.org/crossroads/xrds3-3/colour.html Crossref 